\title{
NOTES ON PORTO RICAN THYSANOPTERA
}

By H. L. DOZIER ${ }^{1}$

The writer is greatly indebted to Dr. J. D. Hood who has kindly confirmed or determined the species recorded in this short paper.

\section{Franklinothrips vespiformis (Crawford)}

Ten adults taken on guava foliage in association with Selenothrips rubrocinctus and the guava whitefly, Aleurodicus minimus, September 21, 1924, at Río Piedras. Also collected in bloom of cultivated rose May 24, 1925.

Aleurodothrips fascia. pennis Franklin

From citrus material infested with Soft and Purple Scale, May 24, 1925, at Río Piedras.

Selenothrips rubrocinctus (Giard)

This species wa's present in the adult and last instar in large numbers September 18, 1924, attacking the underside of foliage of a muscadine grape imported from Florida on the experimental grape plot

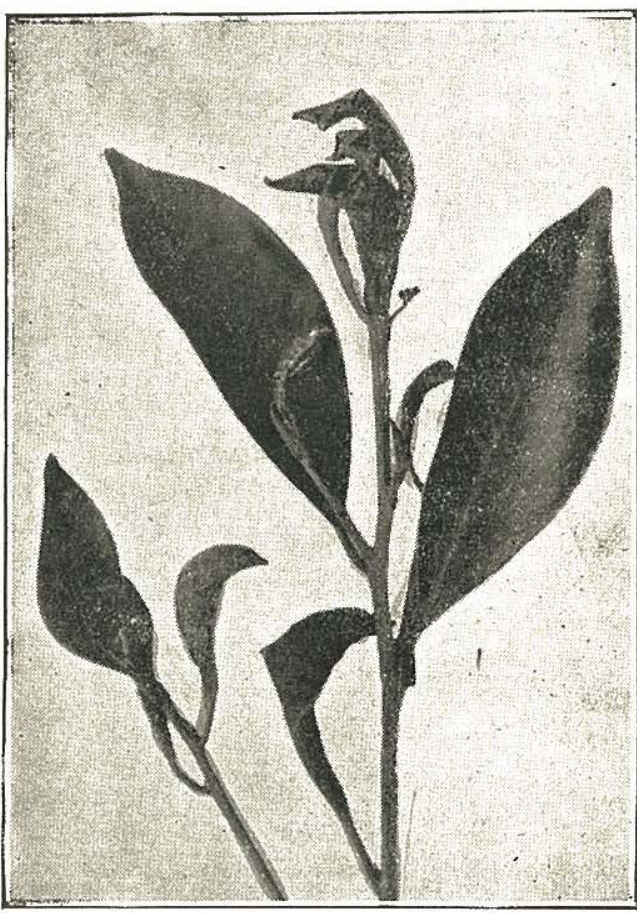

FIG. 1.-Typical work of the Cuban Laurel Thrips, Gynaikothrips uzeli, on "Laurel de India", at the Station. While serious damage was done to the muscadine, other varieties adjacent were not attacked, including the native grape, Califormian varieties, Vitis amurensis and the Carmen. On Uctober 28th, this thrip was abundant on an imported variety of riango, on guava, and on almendra, Terminalia catappa. On No-

\footnotetext{
${ }^{1}$ Formerly Chief Entomologist of the Insular Experiment Station.
} 
vember 1st it was found attacking young leaves of the mangosteen, Garcinia mangostana, and on the 5th the Burbank Thornless Blackkerry in the berry plots was extremely badly infested and nearly comple ${ }^{+}$ely defoliated. The Himalaya Raspberry, Rubus ellipticus, was also generally attacked and the Cuthbert Raspberry was very slightly infested. The native berry was not attacked.

\section{Gynaikothrips uzeli (Zimm.)}

At all seasons of the year this thrips may be found abundant, curling the leaves and growing tips of the "Laurel de India", Ficus nitida Thunb., wherever the latter occurs on the Island. Two predaceous anthocorid sucking bugs, Macrotracheliclla nigra Parshley and Cardiostethus sp., were attacking this thrip in abundant numbers at Juana Díaz, February 11, 1925 . Trees at San Juan were found heavily infested July 2, 1925.

\section{Heliothrips haemorrhoidalis Bouche}

Abundant breeding on leaves of an introduced plant, Barringtonia rpeciosa, at Río Piedras, May 24, 1925.

\section{Frankliniella insularis (Franklin)}

This is the most common species of flower thrips over the Island, attacking many different flowers-in blooms of Canavali maritimus on the beach at Santurce, January 6, 1925; abundant in blooms of "granadilla", Passiflora quadrangularis, June 17, 1925; in rose blooms at Río Piedras, May 24, 1925.

\section{Frankliniella triciti (Fitch)}

Taken in blooms of grape fruit at Trujillo Alto.

\section{Haplothrips merrilli Watson}

Specimens of what has been placed dubiously as this species have been obtained from parasite emergence boxes of scale and whitefly inaterial as follows: numerous specimens from Asterolecanium bambusae material on bamboo, Río Piedras, May 31, 1925; one specimen from Pulvinaria iceryi material on sugar cane at Arecibo, May 31, 1925; one specimen from Howardia biclavis on Acalypha, Río Piedras, May 31, 1925; one specimen from Ceroplastes cirripediformis on passion vine; and a single specimen from Aleurothrixus howardi on lignum-vitae at Central Aguirre, July 22, 1925. The faet that this thrips has been reared in each case associated with either scale 
or whitefly material would indicate that the species is most likely predaceous on the young.

Hoplandrothrips reynei Priesner

Several specimens of this large thrips issued from Asterolecaniurn pustulans material on Cassia fistula placed in parasite emergence cages, May 31, 1925, at Río Piedras. This species also is most probably predaceous on young scale and whitefly. 